\title{
TOMASZ BRAŃKA
}

Poznań

\section{Status terytorium zamorskiego Wspólnot Europejskich na przykładzie Grenlandii}

Unię Europejską od 1 stycznia 2007 r. tworzy 27 państw. Relacje poszczególnych członków ze Wspólnotą nie są jednak jednolite. Wyróżnić można obszary specjalne, które nie są częścią Wspólnoty i co do których nie odnoszą się postanowienia traktatów wspólnotowych. Wśród nich znajdują się kraje i terytoria zamorskie Unii Europejskiej (KTZ) ${ }^{1}$, których szczególne stosunki wynikają z przyczyn instytucjonalnych lub ekonomicznych ${ }^{2}$. Relacje KTZ ze Wspólnotą regulowane są artykułami 182-188 Traktatu ustanawiającego Wspólnotę Europejską (TWE), a wykonywane kolejnymi decyzjami Rady.

Załącznik II TWE wymienia 21 krajów i terytoriów zamorskich. Są to obszary charakteryzujące się specjalnymi powiązaniami z jednym z państw-członków Wspólnoty: 12 z Wielką Brytanią, 6 z Francją, 2 z Holandią i 1 z Danią.

Grenlandia stanowi przykład szczególny. Jako część Królestwa Danii, pomimo sprzeciwu swoich mieszkańców, wstąpiła do Wspólnot razem z Danią w 1973 r. W sześć lat później, po uzyskaniu szerokiej autonomii, lokalny rząd jedną z pierwszych swoich decyzji podjął próbę wyjścia ze Wspólnot, zyskując zrozumienie i pomoc ze strony Danii. Wspólnoty z kolei zezwoliły na bezprecedensowe wycofanie części terytorium państwa-członka, przyznając wyspie bardziej naturalny status terytorium zamorskiego. Ze względu na specyficzne uwarunkowania Grenlandii - m.in. ogromny obszar, niewielką gęstość zaludnienia, skrajne warunki klimatyczne i wypływające z tego wyzwania dotyczące komunikacji i administracji - Wspólnoty postanowiły przyznać wyspie szczególne uprawnienia. Żaden inny KTZ nie odnosi z racji swojego statusu takich korzyści, jak właśnie Grenlandia. Od 2007 r. stosunki Wspólnoty z Grenlandią opierają się na nowej koncepcji dwuaspektowego partnerstwa, składającego się z porozumienia w sektorze rybołówstwa oraz wszechstronnej współpracy w sektorach innych niż rybołówstwo.

Postanowienia odnośnie krajów i terytoriów zamorskich znajdują się w artykułach 182-188 Traktatu ustanawiającego Wspólnotę Europejską. Na ich mocy wybrane państwa członkowskie zgodziły się stowarzyszyć ze Wspólnotą swoje kraje i terytoria pozaeuropejskie. Celem stowarzyszenia jest promowanie rozwoju gospodarczego i społecznego krajów i terytoriów oraz ustanowienie ścisłych stosunków gospodarczych między nimi a Wspólnotąjako całością. Stowarzyszenie ma służyć przede wszystkim sprzyjaniu interesom i pomyślności mieszkańców tych krajów i terytoriów (artykuł 182).

1 Overseas Countries and Territories - OCT.

2 Z. Czachór, A. Graś, Vademecum: Europa od A do Z, Warszawa 2006, s. 101. 
Dzięki stowarzyszeniu państwa członkowskie stosują w wymianie handlowej z krajami i terytoriami takie same warunki, jak między sobą na podstawie Traktatu Rzymskiego. Konsekwentnie, każdy kraj lub terytorium w wymianie handlowej z państwami członkowskimi i innymi KTZ stosuje takie zasady, jak względem państwa europejskiego, z którym utrzymuje szczególne stosunki.

Artykuł 184 TWE wyraźnie wskazuje, że cła na przywóz do państw członkowskich towarów pochodzących z KTZ są zakazane. W przypadku przywozu towarów z państw członkowskich do kraju lub terytorium zamorskiego cła zakazane są ogólną zasadą. Z uwagi jednak na potrzeby rozwojowe KTZ, władze KTZ, mogą utrzymać lub wprowadzić w odniesieniu do przywozu towarów pochodzących ze Wspólnoty należności celne lub ograniczenia ilościowe, jakie uznają za konieczne. Przyjęte zasady handlu nie moga jednak powodować żadnej dyskryminacji pomiędzy państwami członkowskimi; nie mogą również być mniej korzystne niż klauzula najwyższego uprzywilejowania. Podobnie Wspólnota, w szczególnych sytuacjach, ma możliwość wprowadzenia środków ochronnych.

Załącznik II Traktatu Ustanawiającego Wspólnotę Europejską wymienia 21 krajów i terytoriów zamorskich Wspólnoty:

- Grenlandia,

- Nowa Kaledonia oraz terytoria zależne,

- Polinezja Francuska,

- Francuskie Terytoria Południowe i Antarktyczne,

- Wyspy Wallis i Futuna,

- Mayotte,

- Saint Pierre i Miquelon,

- Aruba,

- Antyle Niderlandzkie:

- Bonaire,

- Curaçao,

- Saba,

- Sint Eustasius,

- Sint Maarten,

- Anguilla,

- Kajmany,

- Falklandy,

- Georgia Południowa i Wyspy Sandwich Południowy,

- Monserrat,

- Pitcairn,

- Święta Helena i terytoria zależne,

- Brytyjskie Terytoria Antarktyczne,

- Brytyjskie Terytorium Oceanu Indyjskiego,

- Wyspy Turks i Caicos,

- Brytyjskie Wyspy Dziewicze,

- Bermudy.

Postanowienia artykułów 182-188 TWE są wykonywane kolejnymi, jednomyślnymi Decyzjami Rady. Obecnie obowiązuje Decyzja o Stowarzyszeniu Zamorskim 
z 27 listopada 2001 r. $^{3}$, którą stosuje się do 31 grudnia 2011 r. ${ }^{4}$ Szczegółowo określa ona relacje pomiędzy Wspólnotą Europejską a KTZ, przy uwzględnieniu zmian wynikających z Decyzji Rady z 19 marca 2007 r. ${ }^{5}$ Decyzja z 2001 r. wymienia jedynie $20 \mathrm{KTZ}$. Zgodnie z życzeniem rządu Bermudów zasad stowarzyszenia ustanowionych w tej Decyzji nie odnosi się bowiem do tego terytorium.

Realizując cele wymienione art. 182 TWE Wspólnota zamierza skoncentrować się na ograniczeniu, zapobieganiu, a wreszcie zlikwidowaniu ubóstwa, a dalej na trwałym, zrównoważonym rozwoju i stopniowej integracji KTZ z regionem i gospodarką światową. Wśród 20 krajów i terytoriów zamorskich, objętych obowiązującą Decyzja, Wspólnota wskazała grupę „najmniej rozwiniętych KTZ”, które nie są w stanie odnieść korzyści ze współpracy regionalnej i integracji. W celu ułatwienia takim obszarom przezwyciężenia strukturalnych i pozostałych przeszkód w ich rozwoju Wspólnota wprowadziła szczególne ich traktowanie przy ustalaniu wielkości środków finansowych. Priorytet przyznano poprawie warunków życia w najuboższych warstwach ludności. Do grupy „najmniej rozwiniętych KTZ” zaliczono: Anguilla; Mayotta; Monserrat; Święta Helena, Wyspy Wniebowstapienia, Tristan da Cunha; Wyspy Turks i Caicos; Wyspy Wallis i Futuna oraz Saint-Pierre i Miquelon ${ }^{6}$.

W Preambule Decyzji o Stowarzyszeniu Zamorskim z 2001 r. Rada wyraźnie wskazała, że pomimo iż KTZ nie są państwami trzecimi, to nie stanowią one części jednolitego rynku i muszą przestrzegać zobowiązań nałożonych na państwa trzecie w odniesieniu do handlu. Jednocześnie zauważono, że poziom taryf celnych odgrywa coraz mniejszą rolę $\mathrm{w}$ równym dostępie do rynku. Rosnącego znaczenia nabierają natomiast handel usługami i dziedziny związane z handlem. Stąd postulat stopniowej integracji z gospodarką regionalną i globalną tych KTZ, które będą tym zainteresowane.

W Decyzji wskazano, że bezcłowy dostęp dla pewnych produktów pochodzących z KTZ wywołuje lub grozi wywołaniem poważnych zakłóceń w funkcjonowaniu niektórych wspólnych organizacji rynku w ramach wspólnej polityki rolnej. W szczególności ostrzeżenie to odnosiło się to do rynków ryżu i cukru ${ }^{7}$. Sytuacja taka doprowadziła po raz pierwszy do przyjęcia przez Komisję i Radę odpowiednich środków ochronnych ${ }^{8}$. Decyzja precyzuje jednak, iż w momencie zaistnienia zagrożenia za każdym razem

3 Decision 2001/822/EC of 27.11.2001, OJ L314, 30.11.2001, p. 1.

4 Poprzednia Decyzja Rady 91/482/EWG z dnia 25 lipca 1991 r. w sprawie stowarzyszenia krajów i terytoriów zamorskich z Europejską Wspólnotą Gospodarczą stosowana była do 1 grudnia $2001 \mathrm{r}$. Por. Dz. U. L 236 z 19.09.1991 r.

5 Decyzja Rady z dnia 19 marca 2007 r. zmieniająca decyzję 2001/822/WE w sprawie stowarzyszenia krajów i terytoriów zamorskich ze Wspólnotą Europejską, Dziennik Urzędowy Unii Europejskiej, L 109 z 26.4.2007, s. 33-41.

6 Por. Załącznik I B Decyzji o Stowarzyszeniu Zamorskim, Dz. U. L 314 z 30.11.2001. Wykaz zmieniany jest na mocy decyzji Rady, działającej jednomyślnie na wniosek Komisji.

7 Wspólnoty skupiły swoją uwagę zwłaszcza na zasadach pochodzenia pozwalających na kumulację produktów pochodzących z państw Afryki, Karaibów i Pacyfiku.

8 Zakłócenia na Wspólnotowym rynku wynikały z faktu, iż sprowadzony bezcłowo cukier i ryż pochodziły z państw trzecich, a w KTZ były jedynie przetwarzane, a następnie eksportowane, już jako oryginalne produkty KTZ. W efekcie Wspólnota postanowiła stopniowo, przy stale malejących limitach ilościowych, wycofać się z zasad kumulacji dla produktów sektora cukru do $2011 \mathrm{r}$. W przypadku ryżu zdecydowano się na wprowadzenie limitów ilościowych. 
pierwszeństwo należy dać tym środkom, które w najmniejszym stopniu mogłyby zakłócić funkcjonowanie stowarzyszenia i Wspólnoty. Środki te muszą być także adekwatne do zaistniałej sytuacji i nie mogą przekraczać zakresu absolutnie niezbędnego do wyeliminowania powstałych trudności. Szczególną uwagę należy przy tym zwrócić na interesy najmniej rozwiniętych KTZ.

W sprawie pomocy finansowej dla KTZ Rada uznała, że powinna ona być przydzielana na podstawie ,jednolitych, przejrzystych i skutecznych kryteriów”. Podział kwot pomiędzy poszczególne KTZ uwzględnia przede wszystkim: gospodarcze i naturalne warunki KTZ; wykorzystanie środków przydzielonych w przeszłości; poszanowanie zasady należytego zarządzania finansami, a także szacowaną zdolność absorpcji środków. Dotychczasowe doświadczenia, uznające zdolność władz KTZ do zarządzania, skłaniają do rozdysponowania środków finansowych bardziej na zasadzie partnerstwa, w oparciu o przepisy obowiązujące w odniesieniu do funduszy strukturalnych. W konsekwencji główną odpowiedzialność za programowanie i wdrażanie współpracy przeniesiono na poszczególne KTZ. Władze tych krajów i terytoriów przygotowują zatem, razem z Komisją i państwem członkowskim, z którym dany KTZ jest związany, jednolite dokumenty programowe (JDP) oraz programy współpracy, w których wskazuje się strategię i cele priorytetowe.

W okresie od 1 marca 2000 r. do 28 lutego 2005 r. ogólna kwota wspólnotowej pomocy finansowej w ramach 9. Europejskiego Funduszu Rozwoju (9. EFR) dla KTZ wyniosła $175 \mathrm{mln}$ euro. $Z$ tej kwoty $153 \mathrm{mln}$ euro przeznaczono na pomoc w formie dotacji, $20 \mathrm{mln}$ euro na finansowanie instrumentu inwestycyjnego $\mathrm{KTZ}^{9}$, a 2 mln euro na badania lub środki pomocy technicznej z inicjatywy Komisji.

Pomoc w formie dotacji objęła głównie wsparcie długoterminowego rozwoju, pomoc humanitarna, pomoc w sytuacjach wyjątkowych oraz pomoc dla uchodźców. Na te dziedziny przeznaczono łącznie $145 \mathrm{mln}$ euro. $Z$ tej sumy $66,1 \mathrm{mln}$ euro przewidziano dla tych KTZ, których rozwój gospodarczy jest najmniej zaawansowany, a których PNB per capita nie przekracza 75\% PNB Wspólnoty. Pozostałą część, 61 mln euro, przeznaczono na pomoc dla tych KTZ, których PNB per capita nie przekracza poziomu PNB Wspólnoty ${ }^{10}$. W ramach 9. EFR największą pomoc otrzymały Antyle Niderlandzkie (20 mln euro), Mayotta (15,2 mln euro) oraz Nowa Kaledonia (13,75 mln euro).

Decyzja Rady z 19 marca 2007 r. w sprawie zmiany decyzji w sprawie stowarzyszenia krajów i terytoriów zamorskich ze Wspólnotą Europejską określa rozdział kwot w związku z ustanowieniem 10. Europejskiego Funduszu Rozwoju (10. EFR) na lata 2008-2013. Łączna kwota środków przydzielonych z 10. EFR jest o ponad 30\% wyższa w stosunku do kwoty przyznanej z 9 . EFR ${ }^{11}$.

9 Instrument Inwestycyjny KTZ wymieniony jest w Załączniku II C do Decyzji o Stowarzyszeniu Zamorskim z 2001 r. Jego celem jest wspieranie rentownych przedsiębiorstw, głównie w sektorze prywatnym, lecz także przedsiębiorstw w sektorze publicznym wspierających rozwój sektora prywatnego. Zob. także: zmiany wynikające z Decyzji Rady z 19 marca 2007 r., Dz. U. L 109 z 26.4.2007, s. 38-39.

10 Pozostałą kwotę 17,9 mln euro, jako nie przydzieloną rezerwę, odłożono w celu finansowania pomocy humanitarnej i pomocy dla uchodźców, dokonania nowych przydziałów środków oraz zmian wynikających z przewidzianej oceny porozumienia o warunkach połowów z Grenlandią.

${ }_{11}$ Raport generalny na temat działalności Unii Europejskiej 2006, Komisja Europejska, Bruksela-Luksemburg 2007, s. 186. 
Ogólna kwota, która ma zostać przyznana KTZ w tym okresie, została ustalona na $286 \mathrm{mln}$ euro. Ponownie zadbano o „szczególne traktowanie” najsłabiej rozwiniętych KTZ, jak również tych, które z powodu izolacji geograficznej oraz innych ograniczeń mają większe trudności w nawiązywaniu współpracy. Zwrócono uwagę na potrzebę silniejszej współpracy pomiędzy KTZ a państwami Afryki, Karaibów i Pacyfiku (państwami AKP) oraz regionami najbardziej oddalonymi, które wymienia art. 299 ust. 2 TWE, czyli francuskimi departamentami zamorskimi, Azorami, Maderą i Wyspami Kanaryjskimi.

W ramach kwoty $286 \mathrm{mln}$ euro, $250 \mathrm{mln}$ euro przeznaczono na wsparcie długoterminowego rozwoju, pomoc humanitarna, pomoc w sytuacjach wyjątkowych oraz pomoc dla uchodźców; $30 \mathrm{mln}$ na finansowanie instrumentu inwestycyjnego $\mathrm{KTZ}^{12}$, a $6 \mathrm{mln}$ euro na badania lub środki pomocy technicznej. Z kwoty $250 \mathrm{mln}$ euro $195 \mathrm{mln}$ euro zostanie przeznaczonych na finansowanie inicjatyw priorytetowych służących rozwojowi społecznemu i ochronie środowiska naturalnego $\mathrm{w}$ ramach walki z ubóstwem. Zasadniczo o finansowanie w ramach tej części pomocy mogą ubiegać się te KTZ, których PNB per capita nie przekracza PNB per capita mieszkańca Wspólnoty. Pozostałą kwotę, $40 \mathrm{mln}$ euro, przeznaczono na wsparcie integracji regionalnej oraz na działania na wypadek katastrof.

KTZ kwalifikują się także do uzyskania finansowania na rzecz krajów rozwijających się. Obecnie korzystają one z 3 działań przyjętych dla krajów rozwijających się w ogólnym budżecie Unii Europejskiej ${ }^{13}$.

Zgodnie z Decyzją Rady z 2001 r. (art. 11-17) Współpraca Wspólnoty z KTZ obejmuje następujące dziedziny:

- sektory produkcyjne (m.in.: rolnictwo, leśnictwo, rybołówstwo, rozwój obszarów wiejskich, przemysł, górnictwo, energetyka, transport, komunikacja, gospodarka wodna, bankowość, badania naukowe);

- rozwój handlu (m.in.: wspieranie określenia właściwej polityki makroekonomicznej; tworzenie właściwych ram prawnych; ustanowienie spójnej strategii handlowej; rozwój zasobów ludzkich; pomoc w stosowaniu nowoczesnych technik marketingowych; zakładanie i rozwój instytucji ubezpieczeniowych i kredytowych);

- handel uslugami (m.in.: rozwój infrastruktury, usług transportu morskiego, lotniczego; wspieranie telekomunikacji podstawowej; działanie na rzecz trwałej turystyki);

- dziedziny związane $\mathbf{z}$ handlem (m.in.: ochrona i egzekwowanie prawa własności intelektualnej; szersze stosowanie międzynarodowych przepisów technicznych, norm i procedur oceny zgodności; ochrona środowiska naturalnego; współpraca w odniesieniu do norm pracy, ochrony zdrowia ludzi, zwierząt i roślin);

- sektory społeczne (m.in.: rozwój czynnika ludzkiego i społecznego; polityka edukacyjna; sektor ochrony zdrowia; polityka ludnościowa i planowanie rodziny; budow-

\footnotetext{
12 Zmienione postanowienia odnośnie instrumentu inwestycyjnego KTZ zawiera Decyzja Rady z 19 marca 2007 r., w załączniku I (Załącznik IIAa). Por. przypis 9.

13 Więcej zob.: Decyzja Rady z dnia 19 marca 2007 r. zmieniająca decyzję 2001/822/WE w sprawie stowarzyszenia krajów i terytoriów zamorskich ze Wspólnotą Europejską, Dz. U. L 109 z 26.4.2007, Załącznik II E: Wspólnotowa pomoc finansowa: pomoc budżetowa dla krajów rozwijających się.
} 
nictwo mieszkaniowe i programy urbanizacji; zapobieganie produkcji, dystrybucji i przemytowi wszystkich rodzajów narkotyków);

- wspólpraca i integracja regionalna (współpraca w ramach KTZ; współpraca KTZ z państwami AKP; dążenie do stopniowej integracji KTZ z gospodarką światowa);

- współpraca kulturalna i społeczna (wspieranie tożsamości kulturowej i dialogu międzykulturowego; rozwój zasobów ludzkich).

Ocenie wyników stowarzyszenia, a także wymianie opinii na temat szczegółowych procedur, ma służyć Forum dialogu krajów i terytoriów zamorskich z Unią Europejska, zbierające się raz $\mathrm{w}$ roku ${ }^{14}$. Forum przewodniczy Komisja, która zapewnia również działanie jego sekretariatu.

Zgodnie z art. 58 Decyzji Rady z 2001 r. kraje i terytoria zamorskie są również uprawnione do uczestnictwa w wybranych programach wspólnotowych. Decyzją Rady z 2007 r., KTZ korzystają z następujących programów:

- edukacji i kształcenia;

- Programu w ramach Programu ramowego na rzecz konkurencyjności i innowacji;

- Programu w ramach siódmego Programu Ramowego WE w dziedzinie badań, rozwoju technologicznego i demonstracji;

- Programów kulturalnych i audiowizualnych oraz Programu szkolenie zasobów ludzkich w Japonii (HRTP Japan) ${ }^{15}$.

W przypadku uzyskania niepodległości przez KTZ uzgodnienia przewidziane w Decyzji Rady z 2001 r. mogą być dalej tymczasowo stosowane, zgodnie z warunkami ustalonymi przez Radę. W szczególności odnosi się do pomocy finansowej.

Szczególny status Grenlandii w jej relacjach ze Wspólnotą wynika z uznania bliskich związków historycznych, politycznych i gospodarczych łączących Europę z Grenlandią, a także z faktu bycia częścią Wspólnoty i trwałych związków, jakie ustanowiono pomiędzy Wspólnotą Europejską a Grenlandią w 1985 r.

Dania pomimo swojej złożonej struktury - w jej skład wchodzą dwa terytoria autonomiczne: Grenlandia i Wyspy Owcze - jest państwem unitarnym. W trakcie prowadzenia negocjacji akcesyjnych Wyspy Owcze cieszyły się stosunkowo szeroką autonomią nadaną w 1948 r. Inny był status Grenlandii - ta na mocy Konstytucji Królestwa Danii z 1953 r., przestała być kolonią i została uznana za pełnoprawną część Królestwa. Autonomię - wzorowaną w znaczącej mierze na rozwiązaniach zastosowanych na Wyspach Owczych - wprowadzono dopiero w 1979 r.

Dzięki swojemu autonomicznemu statusowi Wyspy Owcze, jako europejskie terytorium państwa-członka Wspólnot, uzyskały zgodę nie tylko na to, by decyzję o członkostwie podjąc w ciagu trzech lat, od wstapienia państwa macierzystego, ale w konsekwencji również na pozostanie poza strukturami Wspólnoty. Odpowiednią derogację ustalił ar-

${ }^{14}$ W celu praktycznego wdrożenia celów i zasad Decyzji Rady o Stowarzyszeniu Zamorskim z 2001 r. ustalono trójstronne konsultacje w ramach partnerstwa między Komisją, państwem członkowskim, z którym dane KTZ jest związane i każdym z KTZ, reprezentowanym przez jego władze. Każdy kraj i terytorium posiada również grupy robocze partnerstwa, działające w charakterze doradczym.

15 Więcej zob.: Decyzja Rady z dnia 19 marca 2007 r. zmieniająca decyzję 2001/822/WE..., op. cit., Załącznik IV: Załącznik II F: Pozostała pomoc wspólnotowa: uczestnictwo w programach wspólnotowych. 
tykuł 299(6a) ${ }^{16}$ Traktatu Ustanawiającego Wspólnotę Europejską, który stanowi, że: „niniejszy Traktat nie ma zastosowania do Wysp Owczych”. Obecne relacje ze Wspólnotą Wyspy Owcze opierają na umowie handlowej, która może być wymówiona przez każdą ze stron z 6-miesięcznym okresem wypowiedzenia.

W odróżnieniu od Wysp Owczych Grenlandia nie miała możliwości samodzielnego zadecydowania o członkostwie w Europejskiej Wspólnocie Gospodarczej. Duńskie negocjacje i akcesja miały miejsce zanim największa wyspa świata uzyskała autonomię. Pomimo, że wyniki głosowania w sprawie członkostwa były na Grenlandii zdecydowanie negatywne, wyspa, jako część Królestwa, stała się członkiem Wspólnot. Paradoksalnie, ten wyraźny brak poszanowania woli Grenlandczyków stał się jednym z impulsów do walki o większą niezależność od władz centralnych, co zostało ukoronowane przyznaniem autonomii. Jedną z pierwszych decyzji lokalnego rządu było podjęcie próby wyjścia ze struktur europejskiej organizacji ${ }^{17}$.

W Królestwie Danii referendum akcesyjne, które miało objąć zarówno Danię, jak i Grenlandię, przewidziano na 2 października 1972 r. W międzyczasie jednak, w marcu 1972 r., grenlandzka Rada Prowincji, zaproponowała, aby referendum na Grenlandii zostało przełożone na późniejszy termin. Jak tłumaczono dodatkowy czas należało wykorzystać na przygotowanie dokładniejszej analizy korzyści i kosztów wyspiarskiego członkostwa we Wspólnotach. Argumentowano również, że w ten sposób głosy mieszkańców Grenlandii nie wpłynęłyby na ogólne wyniki referendum w samej Danii. Grenlandzką propozycję, zgłoszoną jednak stosunkowo późno, odrzucono ${ }^{18}$.

W wyniku październikowego referendum 63,3\% wszystkich głosujących opowiedziało się za przystapieniem Danii do Wspólnot, przy niezwykle wysokiej frekwencji wynoszącej 90\%. Na Grenlandii jednak wyraźną przewagę zyskali przeciwnicy akcesji - takich głosów było bowiem 70,3\%. Nie miało to jednak większego znaczenia, jako że wyspa będąca wówczas częścią Królestwa Danii, musiała pójść w ślady państwa macierzystego i z dniem 1 stycznia 1973 r. stała się pełnoprawnym członkiem Wspólnot.

Kiedy w sześć lat później, 1 maja 1979 r., na wyspie zaczął obowiązywać Akt Autonomii, jedna z pierwszych decyzji lokalnego parlamentu dotyczyła wycofania Grenlandii z europejskiej organizacji. W lutym 1982 r. na wyspie odbyło się referendum konsultacyjne na temat pozostania wyspy w strukturach organizacji. Większość Grenlandczyków opowiedziała się przeciwko kontynuacji członkostwa; choć tym razem taką opcję wybrało $52 \%$ głosujących, przy frekwencji wynoszącej $75 \%{ }^{19}$. Pomimo niewielkiej przewagi przeciwników dalszego członkostwa, lokalny parlament jednogłośnie zadecydował o wystosowaniu do władz duńskich oficjalnej prośby o podję-

${ }^{16}$ Dawny artykuł 227(5).

17 O takiej propozycji mówił już podczas jesiennej sesji Rady Prowincji Grenlandii w 1977 r. jej przewodniczący L. Chemnitz, por. C. Tyszko, Czy Grenlandia pozostanie w EWG, ,Rynki Zagraniczne" 1977 , nr 123, s. 4.

${ }_{18}$ M. Olsen, Perspectives beyond Greenland secession from the EEC, w: Greenland in the Process of Leaving the European Communities, Report from the Conference organized by the Danish Society for European Studies held in KolleKolle, Copenhagen, on January 14-15, 1983, ed. by H. Rasmussen, Copenhagen 1983, s. 25.

19 F. Harhoff, Preface, w: Greenland in the Process of Leaving..., op. cit., s. 6. 
cie negocjacji mających na celu wycofanie Grenlandii ze Wspólnot ${ }^{20}$. Ówczesny premier Danii, Anker Jorgensen, już wcześniej zapowiedział, że jego kraj uszanuje każdą decyzję, jaką wyspiarze podejmą w referendum. Jednocześnie zastrzegł jednak, że Dania nie będzie w stanie zrekompensować wyspie strat spowodowanych utratą wspólnotowych subsydiów ${ }^{21}$.

Grenlandzcy politycy wielokrotnie tłumaczyli motywy, jakie powodowały o wyjściu wyspy ze struktur Wspólnot. Jednocześnie powtarzali, że po stronie europejskiej często spotykali się z zupełnym brakiem zrozumienia dla tej decyzji.

Po pierwsze, podkreślano, że Grenlandia nie jest terytorium europejskim i nie zmienia tego fakt bycia częścią Królestwa Danii. Wskazywano na ogromne kulturowe i technologiczne różnice dzielące państwa-członków Wspólnot a Grenlandią ${ }^{22}$. Wyspa, zaznaczano, jest obszarem rozwijającym się, z produktem krajowym brutto lokującym ją na poziomie innych krajów i terytoriów zamorskich. Po drugie, podkreślono konieczność pozostawienia w gestii młodego lokalnego rządu pełnej kontroli nad rybołówstwem - kluczową gałęzią wyspiarskiej gospodarki. Lokalne władze były przekonane, że cała walka o autonomię wyspy nie miałaby większego sensu, gdyby sprawy rybołówstwa zostały wyłączone z ich kompetencji ${ }^{23}$.

Wydaje się, że szczególną wagę miała właśnie ta druga kwestia. Już w trakcie pierwszych lat członkostwa wyspiarze protestowali przeciwko nadmiernym połowom wspólnotowych jednostek na wodach grenlandzkich. Jako członek Wspólnot Grenlandia nie mogła określać żadnych kwot połowowych dla rybaków z innych państw członkowskich, a grenlandzcy rybacy nie mieli pierwszeństwa odłowów w ramach całkowitego dopuszczalnego połowu (total allowable catch - TAC) ${ }^{24}$. Dodatkowo, brak własnego rolnictwa uniemożliwiał w praktyce korzystanie z większości funduszy Wspólnoty.

Grenlandczycy byli świadomi, że wyjście z europejskiej organizacji oznaczać będzie utratę znacznych subsydiów. Poza niewątpliwymi korzyściami, jakie przyniosła ta wspólnotowa pomoc, wskazywano jednak i na niebezpieczeństwa, jakie z sobą niosła. Podkreślano, że podczas szybkiego rozwoju infrastruktury na Grenlandii, który niewątpliwie mógł zaistnieć dzięki wspólnotowej pomocy, nie brano pod uwagę istotnych kontekstów lokalnych, w tym zwłaszcza braku wykształconej kadry. Z tego powodu wiele inwestycji nie mogło być należycie wykorzystanych. Zwracano również uwagę na coraz większy wpływ „obcych” w sytuacji, gdy Grenlandia walczyła o większą niezależność i kontrolę nad lokalnymi sprawami. Jak określił to Finn Lynge, Inuita, konsultant ds. Grenlandii w duńskim Ministerstwie Spraw Zagranicznych, było to „zbyt dużo Europy, dla byłej europejskiej koloni, by zdołała to przełknąć,25.

Kwestionowane były wreszcie konkretne korzyści, jakie Grenlandia miała odnosić w związku z integracją. Według obliczeń ze strony grenlandzkiej, w trakcie ostatnich

20 T. Høyem, Minister for Greenlandic Affairs addressing the conference at the opening, w: Greenland in the Process of Leaving..., op. cit., s. 9.

${ }_{21}$ Ch. Follett, Greenland to pull out of EEC, „Times” z 22 lutego 1982 r.

${ }^{22}$ Zob. np.: F. Lynge, The Cultural-Technological Contrast, w: Greenland in the Process of Leaving..., op. cit., s. 17-22.

${ }^{23}$ M. Olsen, op. cit., s. 26.

24 F. Harhoff, op. cit., s. 7.

25 Zob. np.: F. Lynge, op. cit., s. 20. 
czterech lat swojego członkostwa w tej organizacji, Grenlandia rocznie otrzymywała, w postaci różnych subsydiów, ok. $160 \mathrm{mln}$ DKK. W tym samym jednak okresie Wspólnoty uzyskały dostęp do bogatych grenlandzkich łowisk, co rocznie dawało im ok. 585 mln DKK dochodu ${ }^{26}$. Co więcej, wspólnotowa flota dopuszczała się połowów powyżej ustalonych kwot oraz żądała ich zwiększenia poza limity wskazywane przez naukowców, jako bezpieczne dla odnowienia się zasobów żywych ${ }^{27}$. Dodatkowo, wejście Grenlandii do europejskiej organizacji doprowadziło do wzrostu cen żywności na wyspie, co z kolei obciążyło wyspiarzy dodatkową kwotą ok. $40 \mathrm{mln} \mathrm{DKK}^{28}$.

Strona grenlandzka wyrażała jednocześnie nadzieję, że decyzja o wyjściu ze Wspólnot nie będzie w konsekwencji oznaczała pogorszenia stosunków ani z samą Danią, ani z organizacją. Zapewniono również, że nie wpłynie to na stabilność i bezpieczeństwo w północnoatlantyckiej hemisferze ${ }^{29}$. Podkreślano, że Grenlandia dopiero na początku lat osiemdziesiątych XX w. uzyskała realne narzędzia kształtowania i rozwoju swojej odrębnej od Europejczyków tożsamości ${ }^{30}$, a ściślejsza integracja te możliwości ogranicza.

W tej sytuacji rząd Danii wystosował do Wspólnot propozycję modyfikacji Traktatu Rzymskiego, w celu zmiany pełnego członkostwa Grenlandii i przyznania wyspie statusu, jaki przysługuje terytoriom i krajom zamorskim. Duńska propozycja opierała się na postanowieniach artykułu 226 Traktatu Rzymskiego, który stanowił, że: „,[r]ząd każdego Państwa Członkowskiego lub Komisja mogą przedkładać Radzie propozycje zmiany niniejszego Traktatu" oraz że ,[z]miany takie wchodzą w życie po ich ratyfikowaniu przez wszystkie Państwa Członkowskie, zgodnie z ich odpowiednimi wymogami konstytucyjnymi",31.

Duńska propozycja została zaprezentowana Komisji Europejskiej w maju 1982 r. i - jak można się było tego spodziewać - wywołała szerokie reperkusje $\mathrm{e}^{32}$. Początkowo podnoszono, że żadna część Wspólnoty nie powinna jej opuszczać, a zgoda na wyjście Grenlandii ze Wspólnot stworzy niebezpieczny precedens. Grenlandczycy kontrargumentowali, że Wspólnoty, oparte wszakże na demokratycznych zasadach, nie mogą być więzieniem, a sama duńska propozycja w rzeczywistości wnosi o zmianę statusu Grenlandii z członka na terytorium zamorskie ${ }^{33}$. W odpowiedzi, przedstawionej w lutym następnego roku, Komisja odniosła się do noty pozytywnie, zaproponowała jednak przyznanie Grenlandii statusu KTZ na nieco innych od standardowych warunkach, wy-

26 Moses Olsen, b. minister spraw społecznych Grenlandii, podaje nieco niższą kwotę: około 400 mln DKK, zob.: M. Olsen, op. cit., s. 27.

27 Ibidem, s. 25.

28 F. Lynge, op. cit., s. 21.

29 T. Høyem, op. cit., s. 10.

30 F. Lynge, op. cit., s. 22.

31 Traktat Rzymski, Eur-Lex: http://eur-lex.europa.eu/pl/treaties/dat/11957E/word/11957E.doc (2 sierpnia 2006).

32 Zob. np.: I. Murray, Greenland puzzles EEC, „Times” z 4 lutego 1983 r.; I. Murray, Formula for Greenland's exit approved by EEC, ,Times” z 9 lutego 1984 r.

33 P. Lachmann, The Negotiations for Greenland's Withdrawal from the Community and its Inclusion in the OCT-arrangement, w: Greenland in the Process of Leaving the European Communities..., op. cit., s. 54 . 
nikających z zaproponowanego porozumienia o rybołówstwie pomiędzy Wspólnotami a Grenlandią.

W konsekwencji, na mocy tzw. Traktatu Grenlandzkiego ${ }^{34}$, przyjętego 13 marca 1984 r. Grenlandia opuściła struktury Wspólnot ${ }^{35}$. Traktat wszedł w życie dopiero 1 lutego 1985 r., a opóźnienie wynikało z braku ratyfikacji odpowiedniego aktu przez parlament irlandzki oraz przedłużających się rokowań z pozostałymi państwami-członkami ${ }^{36}$. Celem Traktatu Grenlandzkiego była weryfikacja Traktatów ustanawiających Wspólnoty Europejskie tak, aby przestały one wiązać Grenlandię, a jednocześnie wprowadziły nowe porozumienia regulujące stosunki między Wspólnotami a Grenlandią.

W Traktacie, powołując się na artykuł 96 Traktatu ustanawiającego Europejską Wspólnotę Węgla i Stali, artykuł 236 Traktatu ustanawiającego Europejską Wspólnotę Gospodarczą oraz artykuł 204 Traktatu ustanawiającego Europejską Wspólnotą Energii Atomowej państwa członkowskie zadecydowały o wycofaniu Grenlandii ze Wspólnot i wprowadzeniu nowych, specjalnych rozwiązań, regulujących przyszłe relacje pomiędzy Wspólnotami a Grenlandia. Podkreślono, że rozwiązanie, przyjęte w uznaniu „szczególnych cech Grenlandii”,37, powinno cechować się utrzymaniem ścisłych i trwałych więzi pomiędzy Wspólnotami a Grenlandią oraz mieć na względzie obopólne interesy, szczególnie związane z rozwojem wyspy. Grenlandii przyznano także status właściwy dla krajów i terytoriów zamorskich, stowarzyszonych ze Wspólnotą, z zastrzeżeniem konieczności ustanowienia dodatkowych specyficznych postanowień.

Na mocy Traktatu wprowadzono następujące zmiany: do artykułu 79 Traktatu ustanawiającego EWWiS oraz artykułu 198 Traktatu ustanawiającego EWEA dodano punkty o brzmieniu: „niniejszy Traktat nie ma zastosowania do Grenlandii”. Do części IV Traktatu ustanawiającego EWG, która dotyczy Stowarzyszenia krajów i terytoriów zamorskich, wprowadzono artykuł 136a, precyzujący, że postanowienia artykułów 131 do 136 stosują się również do Grenlandii, z zastrzeżeniem specyficznych postanowień zawartych w Protokole w sprawie szczególnych ustaleń dla Grenlandii, który stanowi integralną część Traktatu Grenlandzkiego. Jednocześnie Grenlandia została dodana do listy krajów i terytoriów zamorskich, objętych postanowieniami części IV Traktatu ustanawiającego Europejską Wspólnotę Gospodarczą. Specjalny Protokót, dołączony do Traktatu Grenlandzkiego, ustanawiał nieograniczony i bezcłowy dostęp produktów rybołówstwa z Grenlandii do wspólnotowych rynków, w zamian za „satysfakcjonujący dostęp" do grenlandzkich łowisk na podstawie umowy. Traktat Grenlandzki został

34 Pełna nazwa: Traktat zmieniajacy Traktaty ustanawiajace Wspólnoty Europejskie w odniesieniu do Grenlandii, zob.: Treaty amending, with regard to Greenland, the Treaties establishing the European Communities, OJ No. L 29/1, of 1.02.1985, p. 1.

35 Opisując grenlandzką, ,przygodę" z EWG Moses Olsen, b. minister spraw społecznych przywołał słowa brytyjskiego premiera, Harolda Wilsona, iż ,[n]ic nie wystawiło naszej cierpliwości na większą próbę niż Europa”, zob.: M. Olsen, op. cit., s. 29. Zob. również: Ch. Follett, Greenland celebrates EEC exit, „Times” z 2 lutego 1985 r.

36 Jeden z parlamentarzystów francuskich porównał utratę wyspy przez Wspólnoty ze sprzedażą przez Francję Luizjany USA, por. T. Radzimińska, Grenlandia wystapiła z EWG, „Rynki Zagraniczne" 1985 , nr 17, s. 1-2.

${ }^{37}$ „.... in view of the special features of Greenland" - zob. Treaty amending, with regard to Greenland..., op. cit. 
podpisany i ratyfikowany przez wszystkie państwa członkowskie ${ }^{38}$ i zgodnie z postanowieniami wszedł w życie 1 lutego $1985 \mathrm{r}$.

Ze względu na specjalne uregulowania pomiędzy Wspólnotą a Grenlandią wyspa nie może, jak inne KTZ, korzystać z pomocy finansowej Europejskiego Banku Rozwoju (EBR), tak długo, jak w mocy utrzymane są kolejne protokoły do porozumienia o rybołówstwie ${ }^{39}$. Podobnie w przypadku pomocy finansowej w ramach kolejnych EFR nie stosuje się kryterium terytorialnego, ponieważ pomoc w zakresie rozwoju jest dostarczana na podstawie kolejnych protokołów w sprawie połowów. Jednakże dzięki statusowi KTZ Grenlandia uczestniczy w 17 wspólnotowych programach w dziedzinach: edukacji, kultury, badań, komunikacji, przedsiębiorczości oraz technik informatycznych ${ }^{40}$.

Relacje Unii Europejskiej i Grenlandii do 2007 r. opierały się zatem na dwóch filarach: stowarzyszeniu wyspy w ramach KTZ oraz porozumieniu o rybołówstwie.

Pierwsze porozumienie o rybołówstwie pomiędzy Wspólnotą z jednej strony a rządem Danii oraz lokalnym rządem Grenlandii z drugiej strony zostało zawarte 13 marca $1984 \mathrm{r}$. i zaczęło obowiązywać od 1 stycznia $1985 \mathrm{r}$. Ustalono w nim reguły i warunki - w tym rekompensaty dla Grenlandii - prowadzenia połowów przez państwa członkowskie. Umowa podpisana została na okres 10 lat, z możliwością przedłużenia o kolejne 6 lat, jeżeli żadna ze stron nie wymówi porozumienia przynajmniej na 9 miesięcy przed jego wygaśnięciem ${ }^{41}$. Porozumienie wykonywane było poprzez kolejne protokoły; ostatnim protokołem był Czwarty Protokót, który obowiazzywał od 1 stycznia 2001 r. do 31 grudnia 2006 r. $^{42}$

Ostatnie porozumienie ustaliło kwoty połowowe w wyłącznej strefie ekonomicznej Grenlandii dla Wspólnoty, jak również preferencyjny dostęp do dodatkowych połowów na tych wodach. Uzgodniono, że kwoty połowowe przyznane UE mogą być przejęte również przez jednostki spoza Unii. W zamian za dostęp do własnych łowisk Grenlandia otrzymywała w latach 2001-2006 rekompensatę finansową w wysokości

38 W kolejności składania podpisów: Królestwo Belgii, Królestwo Danii, Republika Federalna Niemiec, Republika Grecka, Republika Francuska, Republika Irlandii, Republika Włoska, Wielkie Księstwo Luksemburga, Królestwo Niderlandów, Zjednoczone Królestwo Wielkiej Brytanii i Irlandii Północnej. Tekst Traktatu został przygotowany w 8 równobrzmiących językach o równej mocy prawnej. Depozytariuszem Traktatu jest Republika Włoska.

39 Communication from the Commission to the Council and the European Parliament: Mid Term Review of the Fourth Fisheries Protocol between the EU and Greenland, COM(2002) 697 final, Eur-Lex http://www.eur-lex.europa.eu/LexUriServ/site/en/com/2002/com2002_0697en01.pdf (1 sierpnia 2006).

${ }_{40}$ Lista aktualnych programów, w których uczestniczy Grenlandia dzięki statusowi KTZ zob.: EU programmes via OCT, Greenland Home Rule, http://www.nanoq.gl/English/EU_-_Greenland/EU-programmes_via_OCT.aspx (1 sierpnia 2006).

${ }^{41}$ Umowa była kilkakrotnie zmieniana, zob.: OJ L 1985, 29, 8; OJ L 2004, 237, 3-4. Kolejne modyfikacje tych postanowień miały postać wymiany listów (OJ L 1994, 351, 15; OJ L 2000, 329, 46) oraz protokołów (OJ L 2001, 209, 1; OJ L 2003, 343, 37; OJ L 2004, 237, 1). Por.: J. Sozański, Porozumienia międzynarodowe Wspólnot i Unii Europejskiej w świetle norm acquis commununitaire oraz Konstytucji dla Europy, z uwzględnieniem orzecznictwa trybunału Sprawiedliwości: studium prawnotraktatowe, Torun 2007, s. 211.

42 Fourth Protocol laying down the conditions relating to fishing provided for in the Agreement on fisheries between the European Economic Community, on the one hand, and the Government of Denmark and the Home Rule Government of Greenland, on the other, Official Journal of the European Communities, L 209/2, 2.8.2001. 
42,82 mln euro rocznie ${ }^{43}$, co stanowi 3,3\% grenlandzkiego PKB. W ramach tej sumy, 31,76 miliona euro rocznie przewidziano jako rekompensatę finansową za zezwolenie na połowy w grenlandzkich łowiskach, a pozostałe 11,05 milionów rocznie na strukturalną pomoc dla sektora rybołówstwa.

W raporcie ze średniookresowego przeglądu Czwartego Protokotu, który miał miejsce w 2002 r., Unia Europejska wskazała na problemy, jakie dotknęły grenlandzką gospodarkę, a które są bezpośrednio powiązane z sytuacją w rybołówstwie. W znaczącej mierze uwaga została poświęcona pogarszającemu się stanowi środowiska naturalnego, w tym postępującemu zanieczyszczeniu wód i powietrza, co ma wpływ na zasoby żywe w grenlandzkich wodach ${ }^{44}$.

Kryzys w rybołówstwie miał bezpośrednie przełożenie na realizację postanowień zawartych w porozumieniu o rybołówstwie i kolejnych protokołach. Unia podnosiła, że na skutek zaistniałej sytuacji kwoty połowowe wskazane w protokołach stały się w znacznej części fikcyjne. Już po ewaluacji pierwszego protokołu w 1985 r. wskazywano, że zaplanowane połowy dorsza i w znacznej mierze karmazyna pospolitego były niemożliwe. Podobna sytuacja miała również miejsce przy ocenie Czwartego Proto$k o ł u$. Ilościowe limity udało się wykorzystać jedynie w stosunku do capelina, krewetek oraz grenlandzkiego halibuta. Pozostałe kwoty wykorzystano jedynie w nikłym procencie: i tak w 2001 r. odłowiono jedynie 19\% kwoty karmazyna pospolitego, mniej niż $3 \%$ kwoty suma oraz mniej niż 1\% dozwolonego odłowu grenadiera. Z kwoty 2000 ton dorsza wspólnotowe jednostki odłowiły jedynie 225 ton. Według wyliczeń Unii rzeczywista wartość grenlandzkich łowisk wyniosła ok. 28 milionów euro (Czwarty Protokót przewidywał zaś kompensację w wysokości 42,8 miliona euro). Zdaniem Wspólnoty pod uwagę nie zostały również wzięte opinie ekspertów, którzy wskazywali, że m.in. kwoty połowowe na dorsza powinny być zawieszone, a tymczasem Czwarty Protokót przewidywał kwotę w wysokości 2000 ton.

Z początkiem 2005 r. rząd Grenlandii przedstawił wniosek dotyczący współpracy pomiędzy Wspólnotą a Grenlandią w czterech sektorach poza sektorem rybołówstwa. W kwietniu propozycja przyjęła postać projektu porozumienia o współpracy i partnerstwie, zwanego Porozumieniem KAYAK. Grenlandia opowiadała się za utrzymaniem dotychczasowej kwoty pomocy na poziomie ok. $42 \mathrm{mln}$ euro oraz zachowaniem bezcłowego dostępu dla produktów grenlandzkich na rynek Wspólnoty. Wśród sektorów innych niż rybołówstwo, kwalifikujących się do objęcia programem zrównoważonej współpracy wymieniono sektory: szkolnictwa i szkolenia; eksploatacji zasobów mineralnych, energii, turystyki, kultury i badań naukowych.

W odpowiedzi na analizę Czwartego Protokołu oraz propozycję Porozumienia KAYAK Komisja w kwietniu 2006 r. zaprezentowała komunikat, dotyczący przyszłego

43 Ibidem, Artykuł 11.

$44 \mathrm{~W}$ rejonie arktycznym, niezwykle wrażliwym ekosystemie, elementami przyśpieszającymi negatywne tendencje była datująca się od lat siedemdziesiątych ubiegłego stulecia nadmierna eksploatacja zasobów żywych wód Północnego Atlantyku oraz zmiany temperatury wody. Dodatkowe ryzyko katastrofy ekologicznej zwiększają plany wzmożonej aktywności na Morzu Arktycznym, związane z poszukiwaniem i wydobyciem ropy naftowej i gazu ziemnego, zob. Communication from the Commission to the Council and the European Parliament: Mid Term Review..., op. cit., s. 4. 
partnerstwa z Grenlandią ${ }^{45}$. Dokument ten stanowił podsumowanie wykonania przez Komisję jej komunikatu dotyczącego średniookresowego przeglądu czwartego protokołu w sprawie połowów.

Wspólnota wyraziła w nim „niezmienne zainteresowanie” traktowaniem Grenlandii jako „uprzywilejowanego sąsiada”, w celu rozwoju wyspy. Komisja uznała, że stosunki pomiędzy Unią a Grenlandią powinny być oparte na politycznym porozumieniu w postaci wspólnej deklaracji. Podkreślono wagę, jaką dla Unii mają stosunki z Grenlandią, szczególnie mając na uwadze:

- zrównoważony rozwój krajów i terytoriów zamorskich;

- współpracę w dziedzinie gospodarowania zasobami rybnymi i środowiskiem morskim oraz umożliwienie połowów dla statków wspólnotowych;

- współpracę na rzecz ograniczenia zmian klimatu;

- promowanie rozwoju alternatywnych źródeł lub nośników energii;

- znaczenie geostrategiczne Grenlandii;

- wspólne badania i rozwój w dziedzinie północnoatlantyckich szlaków żeglugowych oraz grenlandzkiej wyłącznej strefy ekonomicznej.

Jednym z głównych powodów potrzeby nowego uregulowania stosunków pomiędzy Wspólnotą a Grenlandią miała być współpraca w dziedzinach innych niż tylko rybołówstwo. W Konkluzjach Rady z 24 lutego 2003 r. wskazano, że relacje po 2006 r. powinny być oparte na „wszechstronnym partnerstwie na rzecz zrównoważonego rozwoju”, w skład którego wejdzie szczegółowe porozumienie w sprawie połowów ${ }^{46}$. Komisja uzgodniła również, że istnieje potrzeba rozszerzenia i wzmocnienia przyszłych stosunków pomiędzy UE a Grenlandią.

Komisja przychyliła się do opinii, że wsparcie finansowe dla Grenlandii na lata 2007-2013 powinno być utrzymane na dotychczasowym poziomie $(42,8 \mathrm{mln}$ euro rocznie). Z tej sumy, każdego roku, Grenlandia miałaby otrzymać do $25 \mathrm{mln}$ euro na współpracę w sektorach innych niż rybołówstwo. Jednocześnie zaznaczono konieczność wynegocjowania nowego porozumienia o rybołówstwie, które w pełniejszy sposób niż dotychczas odpowiadałoby rzeczywistym relacjom pomiędzy możliwościami połowu na wodach grenlandzkich a przekazywaną wyspie rekompensatą finansową.

Nowe porozumienie, zgodnie ze stanowiskiem Komisji, postanowiono oprzeć na porozumieniu politycznym. 17 lipca 2006 r. przyjęto decyzję Rady w sprawie stosunków łączących Wspólnotę Europejska, z jednej strony, z Grenlandią i Królestwem Danii, $\mathrm{z}$ drugiej strony wraz $\mathrm{z}$ deklaracją na temat partnerstwa ${ }^{47}$. Rozporządzenie wdrążające tę decyzję Rady ukazało się 20 kwietnia 2007 r. ${ }^{48}$ Wspólnota postanowiła rozwijać

45 Komunikat Komisji - Nowa wszechstronna umowa o partnerstwie z Grenlandia w formie wspólnej deklaracji oraz decyzji Rady na podstawie art. 187 traktatu WE z 4 kwietnia 2006 r. (COM/2006/0142 końcowy).

${ }_{46}$ Por. Protokół 2487 sesji obrad Rady Unii Europejskiej (ds. Ogólnych i Stosunków Zewnętrznych) w Brukseli dnia 24 lutego 2003 r., dokument 6604/03 z dnia 2 lutego 2003 r. i biuletyn 1/2-2003, pkt 1.3.175.

47 Decyzja Rady z dnia 17 lipca 2006 r. w sprawie stosunków łączących Wspólnotę Europejską, z jednej strony, z Grenlandią i Królestwem Danii, z drugiej strony, Dz. U. L 208 z 29.7.2006, s. 28-36.

48 Rozporządzenie Komisji Nr 439/2007 z dnia 20 kwietnia 2007 r. wdrażające decyzję Rady 2006/526/WE w sprawie stosunków łączących Wspólnotę Europejską, z jednej strony, z Grenlandią i Królestwem Danii, z drugiej strony, Dz. U. L 104 z 21.4.2007, s. 20-25. 
współpracę z Grenlandią w okresie 2007-2013 na podstawie dwuaspektowego partnerstwa, składającego się z partnerskiego porozumienia w sektorze rybołówstwa z jednej strony oraz wszechstronnej współpracy w sektorach innych niż rybołówstwo z drugiej strony.

We wspólnej deklaracji, motywującej do dalszego wzmacniania stosunków i współpracy, wskazano na bliskie związki historyczne, gospodarcze i kulturalne łączące Europę z Grenlandią. Odwołano się również do ,ścisłych i trwałych" związków pomiędzy Wspólnotą Europejską a Grenlandią, ustanowionych w 1985 r., potwierdzając przy tym istnienie wspólnych interesów. Powtórzono Konkluzje Rady z 24 lutego 2003 r. wskazujące na konieczność rozszerzenia stosunków pomiędzy UE a Grenlandią oraz podkreślono interes geostrategiczny Wspólnoty w traktowaniu wyspy jako uprzywilejowanego sąsiada. Powołano się również na interesy Grenlandii w kontekście „Arktycznego Okna" polityki dotyczącej wymiaru północnego. Uwzględniono także szczególne znaczenie wrażliwego środowiska naturalnego oraz wyzwań, jakie stoją przed ludnością wyspy. Podkreślono wreszcie znaczenie dla Wspólnoty utrzymania działalności połowowej prowadzonej na wodach Grenlandii dla prawidłowego funkcjonowania wspólnej polityki rybołówstwa na północnym Atlantyku. Zrównoważone gospodarowanie zasobami rybnymi oraz środowiskiem morskim, a także zapewnienie możliwości połowowych statkom wspólnotowym uznano za „zasadniczy element partnerstwa” pomiędzy Wspólnotą a Grenlandią.

W decyzji Rady z lipca 2006 r. za cel partnerstwa uznano poszerzenie i wzmocnienie stosunków pomiędzy stronami oraz przyczynianie się do zrównoważonego rozwoju Grenlandii. Szczególną pomoca, poza sektorem rybołówstwa, objęte zostaną dziedziny: edukacji i szkoleń; zasobów mineralnych; energii; turystyki i kultury; badań naukowych oraz bezpieczeństwa żywności. Pomoc finansowa objęła okres od dnia 1 stycznia 2007 r. do dnia 31 grudnia 2013 r. Podobnie, jak w przypadku wcześniejszych umów z Grenlandią, Wspólnota postanowiła, że wraz z rządem Grenlandii i rządem Danii zostanie przeprowadzony śródokresowy przegląd partnerstwa przed końcem $2010 \mathrm{r}$.

Omawiane rozporządzenie Komisji z kwietnia 2007 r. określa procedury programowania, wdrażania, monitorowania, przeglądu i oceny pomocy finansowej Wspólnoty na rzecz Grenlandii.

Wszystkie dotychczasowe umowy z Grenlandią zostały zawarte przez Wspólnotę. Porozumienia te można uznać za umowy międzynarodowe, pomimo istnienia wątpliwości co do istnienia i zakresu ius contrahendi Grenlandii ${ }^{49}$. Stroną porozumień były rząd Danii i lokalna administracja Grenlandii z jednej strony, a Wspólnota z drugiej strony.

Specyfika Grenlandii, jako KTZ, przejawia wreszcie niezwykle ważną rolę w realizacji projektu ,Arktyczne Okno” (Arctic Window) w ramach Pótnocnego Wymiaru Unii Europejskiej (Northern Dimension of European Union). Wymiar Pótnocny jest inicjatywą Unii Europejskiej spinająca całokształt jej polityki wobec Europy Północnej, obejmującej Islandię, Norwegię, region Morza Bałtyckiego oraz północno-europejskie obszary Rosji. Ma on służyć dwóm celom: rozwojowi współpracy regionalnej pomię-

$49 \mathrm{~W}$ przypadku państw niejednolitych, nawet w przypadku państwa unitarnego, jakim jest Królestwo Danii, przyjmuje się, że części składowe mogą wykonywać ius contrahendi w ograniczonym zakresie w sposób przewidziany w Konstytucji. Zob.: J. Sozański, op. cit., s. 211. 
dzy wszystkimi państwami regionu oraz stworzeniu platformy współpracy Unii Europejskiej z Rosją. Inicjatywa powołania Wymiaru Pótnocnego Unii Europejskiej po raz pierwszy została przedstawiona w 1997 r., podczas konferencji Rady Regionu Morza Barentsa w Rovaniemi przez fińskiego premiera, Paavo Lipponena. W czerwcu $2000 \mathrm{r}$. na szczycie Rady Europejskiej w Feirze, Unia przyjęła pierwszy Plan Działań dla Wymiaru Pólnocnego na lata 2000-2003 (Northern Dimension Action Plan) ${ }^{50}$.

Władze Grenlandii uznały, że problemy i wyzwania stojące przed obszarami arktycznymi są w wielu punktach tożsame z celami Pótnocnego Wymiaru. Na unijnym spotkaniu w Helsinkach w grudniu 1999 r., po konsultacjach z innymi przywódcami państw nordyckich, premier Grenlandii, Jonathan Motzfeldt, zaprezentował ideę powołania ,Arktycznego Okna”. Grenlandzki pomysł spotkał się z bardzo przychylnym przyjęciem. W celu dopracowania szczegółów współpracy 28 sierpnia 2002 r. odbyła się w Ilulissat, w północnej Grenlandii, konferencja na temat priorytetów nowego Planu Działania dla Wymiaru Pótnocnego ${ }^{51}$.

Przewodnim tematem współpracy w tym obszarze ma być zrównoważony rozwój w obszarach rzadko zamieszkałych. W ramach Arktycznego Okna znalazło się sześć celów szczegółowych:

1) rozwój handlu i przemysłu w Arktyce;

2) ochrona arktycznego środowiska, zanieczyszczenia transgraniczne, ochrona zasobów żywych;

3) rozwój społeczny;

4) telekomunikacja/społeczeństwo informacyjne;

5) badania, arktyczne know-how;

6) współpraca regionalna i przygraniczna ${ }^{52}$.

W zamyśle Grenlandii „Arktyczne Okno” ma być mostem spinającym region arktyczny z północnymi rubieżami UE i przez to z całą tą organizacją. Grenlandia z racji swojego statusu w ramach systemu KTZ jest niejako predestynowana do odegrania roli łącznika pomiędzy światem arktycznym a UE. W ramach unijnego zaangażowania w projekt „Arktycznego Okna” szczególna uwaga ma być poświęcona także sytuacji ludności tubylczej ${ }^{53}$.

50 Więcej zob.: European Union: External Relations, The Northern Dimension, http://ec.europa.eu/comm/external_relations/north_dim/index.htm (4 sierpnia 2006); Wymiar Pótnocny Unii Europejskiej. Materiały z seminarium (12 października 2001), Centrum Stosunków Międzynarodowych, Raporty i Analizy 1/02; T. Palmowski, ,, Wymiar Pólnocny” Unii Europejskiej, „Stosunki Międzynarodowe" 2004, nr 1-2, t. 29, Warszawa 2004.

51 W Konferencji udział wzięli przedstawiciele państw członkowskich UE, Komisji Europejskiej oraz siedmiu państw partnerskich Pólnocnego Wymiaru: Estonii, Islandii, Łotwy, Litwy, Norwegii, Polski i Federacji Rosyjskiej, por. The Arctic Window, The Greenland Homerule, http://www.dk.nanoq.gl/tema.asp?page=tema\&objno=32274 (30 sierpnia 2006); Conclusion of the Chairman, The Greenland Homerule, http://www.dk.nanoq.gl/nyhed.asp?page=nyhed\&objno=34533 (30 sierpnia 2006).

52 The Arctic Window..., op. cit. Więcej zob.: Report on the Arctic Window, The Greenland Homerule, http://www.nanoq.gl/English/EU_-_Greenland/Speeches_Documents/Greenland_Report,-c-,_An_Arctic_Window.aspx (4 sierpnia $200 \overline{0}$ ).

53 The Arctic Window in the EU's Northern Dimension, Greenland Home Rule, http://www.gh.gl/uk/NEWS/GOVERN/arcticwin.htm (4 sierpnia 2004). 
W przypadku stosunków Wspólnoty z Grenlandią wyraźnie zarysowała się obopólna gotowość do wypracowywania nowych, praktycznych rozwiązań. Szczególnie było to widoczne w przypadku wyrażenia zgody na opuszczenie Wspólnot przez Grenlandię; powszechne były bowiem obawy, że w ten sposób stwarza się niebezpieczny precedens, który w przyszłości może obrócić się na niekorzyść samej organizacji. Grenlandia uzyskała również pomoc ze strony państwa macierzystego, które prowadziło efektywne negocjacje ze Wspólnotami.

W relacjach ze Wspólnotą Grenlandia, jako szczególny przypadek KTZ, uzyskała zamierzone cele: utrzymania wolnocłowego dostępu dla swoich towarów na wspólnotowy rynek, przy zapewnieniu rekompensaty finansowej w dotychczasowej wysokości oraz rozszerzenia współpracy o sektory inne niż rybołówstwo. 